\title{
WINGS IMPROVING DRIVING PARAMETERS
}

MIROSLAV KRATOCHVÍL

CTU Cartech, Czech Republic, Tel.: 731026 487, E-mail: miroslav.kratochvil@fs.cvut.cz

NIKITA ASTRAVERKHAU

CTU in Prague, Technická 4, Czech Republic, Tel.: 739303 214, E-mail: nikita.astraverkhau@fs.cvut.cz

VÍTEK SLANINA

CTU Cartech, Tel.: 728025231

\section{SHRNUTI}

Aerodynamika je nedílnou součástí automobilového průmyslu. Zlepšení jízdních vlastností vozu díky př́tlaku jsou si konstruktéři vědomi již od 60 . let minulého století. Ve Formula Student tomu není jinak. Následující článek představuje návrh aerodynamických prvků týmu CTU Cartech za pomocí CFD analýzy a následného ověření při testování na trati.

KLIĆCVÁ SLOVA: FORMULE STUDENT, EXTERNII AERODYNAMIKA, AERODYNAMICKÉ PRVKY, KŘídLA, PROFIL KŘÍdLA, CTU CARTECH, CDF ANALÝZA, MĚřENÍ

\section{ABSTRACT}

Aerodynamics is integral part of automotive industry. Constructers have been aware of improving the driving performance of cars by downforce since 1960s. In Formula Student it is not otherwise. The following article introduces design of aerodynamic devices by CTU Cartech team using CFD analysis and subsequent road testing verification.

KEYWORDS: FORMULA STUDENT, AERODYNAMIC DEVICES, EXTERNAL AERODYNAMICS, WINGS, AIRFOIL, CTU CARTECH, CFD ANALYSIS, ROAD TESTING

\section{INTRODUCTION}

The usage of aerodynamic devices on race cars is very common today. They increase the normal force on wheels which improves the cornering and braking ability of the car and also the stability at high speeds. Unfortunately the downforce produced by aerodynamic devices is accompanied by an increase of drag. So it is important to find a compromise between the downforce and drag in the design of aerodynamic devices and also count with the aerodynamic forces in the design of other components of the car. By finding the right balance positive results will be obtained in the improvement of the lap-times.

Formula Student is a very specific competition. The main goal is to build an open four wheel prototype vehicle for nonprofessional, weekend, racing competition market [1]. Due to keep safety at the dynamic event the track is full of curves to keep the maximum speed a bit over $100 \mathrm{~km} . \mathrm{h}^{-1}$. It may seem ineffective to deal with aerodynamic devices at these velocities keeping also in mind other negative aspects as additional drag, weight etc. After considering these aspects the question arises whether there are any reasons to use aerodynamic devices in Formula Student?

The aerodynamic package of our car consists of front and rear wing. The external aerodynamics was completely developed by CFD software Star CCM+ and the results have been evaluated at the test track.

\section{THE WINGS DESIGN BY CFD ANALYSIS}

The base element of the wing is the airfoil. The airfoils are identical as in aviation. Due to this, there exist a great amount of the airfoils for different types of use. To choose the best shape of the airfoil you have to set criteria that are important for you. For us the criteria were low Reynolds numbers, high lift coefficient and good efficiency which depends on the ratio of lift and drag. With these requirements we have selected the 


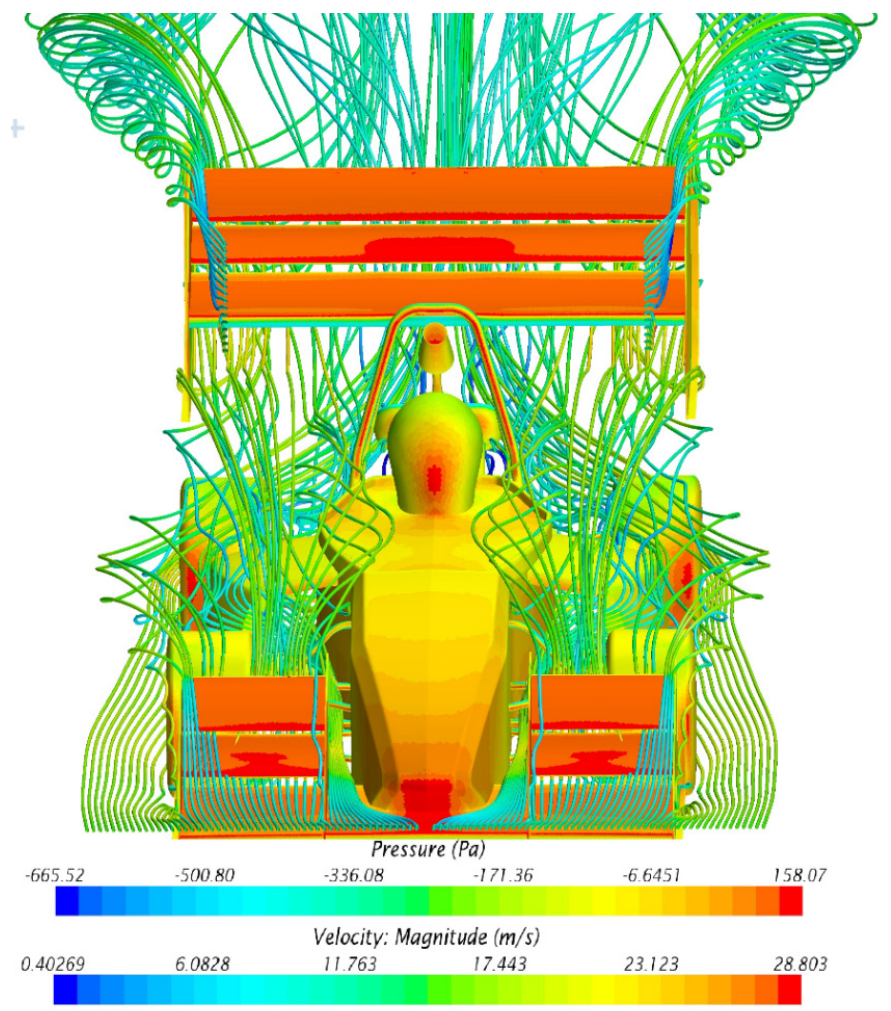

FIGURE 1: 3D CFD analysis of car with pressure distribution and streamlines OBRÁZEK 1: 3D CFD analýza vozu s rozložením tlaku a proudnicemi

Selig's airfoil S1223. The airfoil's parameters were compared for Reynolds numbers in range from 200000 to 600000 .

\section{PARAMETERS OF SELIG'S PROFILE: \\ - Thickness: $11.93 \%$ \\ - Camber: $8.67 \%$}

The parameters are related to the chord line's length of the profile.

Star CCM+ allows creating 3D-CAD geometry in its modeler or importing it using a wide variety of common used file formats. You can also import the mesh file. We import the geometry from CATIA where our model of car is constructed. The model for CFD analysis had to be simplified due to its complexity. For external aerodynamics it is important to create a space around the car big enough for the air to flow. It is necessary to stabilize the flow that is disturbed by car geometry. The size of the flow space is dependent on the size of the obstacle $[2,4]$.

The physical parameters of the simulation were turbulent flow of uncompressible gas and k-epsilon turbulence solver with all $y+$ wall treatment. The function of wall $y+$ treatment secures the velocity distribution near the surface because we count with viscosity of the gas. It is important to create precisely the boundary layer because the flow separation is dependent on it and it can negatively impact the results.

The mesh is another parameter which influences the result. We are using polyhedral elements with the prism layer. They provide a balanced solution for complex mesh generation problems. They are relatively easy and efficient to build, requiring no more surface preparation than the equivalent tetrahedral mesh [3]. The prism layer refines the mesh near the wall. This is important for establishing the boundary layer as is mentioned above. The number of cells effects the demands on the hardware requirements of the computer. It is necessary to consider how big size element where you choose. The size of the cell is also influenced by the complexity of the geometry. The finest elements where used for the wings, tires, suspension, cooling system and the gap between the ground and the bottom of the car. The finest element was not used only on the surface. We create volumes which were filled with the cells of the same size as on the element's surfaces. Bigger elements were on the chassis. Another volume with the same size of the cells as on the chassis was created to estimate flow around the whole car. The remaining space was filled with larger elements. The whole mesh was verified with the function "manage the thresholds". The quality was also verified with cell quality remediation. The cells of poor quality are displayed and you can refine the mesh in these areas.

Because the car is symmetrical, only half of the car needs to be modelled. Still, the count of mesh cells is above 6 million. To approximate reality as much as possible it was necessary to set a moving ground and rotating wheels to the model. These aspects are simulating a drive and strongly influence the behavior of the front wing due to its close position to these elements. The flow around the rotating tires may not look so different than around the stationary wheel, but there is difference in the position of the separation point which is effecting the pressure coefficient. The difference in pressure coefficient influences drag and lift of the wheel $[5,6,10]$.

The main goal was to get the high downforce with reasonable amount of drag. This goal is not straightforward to achieve because there was a space limitation for wings in the rules of Formula Student. An even bigger limitation for us was the narrow track that the car has to pass in the dynamic disciplines. On the track cones are placed. Each cone which is struck down during a race means time penalization. After considering these aspects we decided to use a wing with three elements. It allowed us to design the wing with high curvature and long chord-line. These factors are very important because they influence the downforce of the wing. To specify the angle of attack, slot gap 


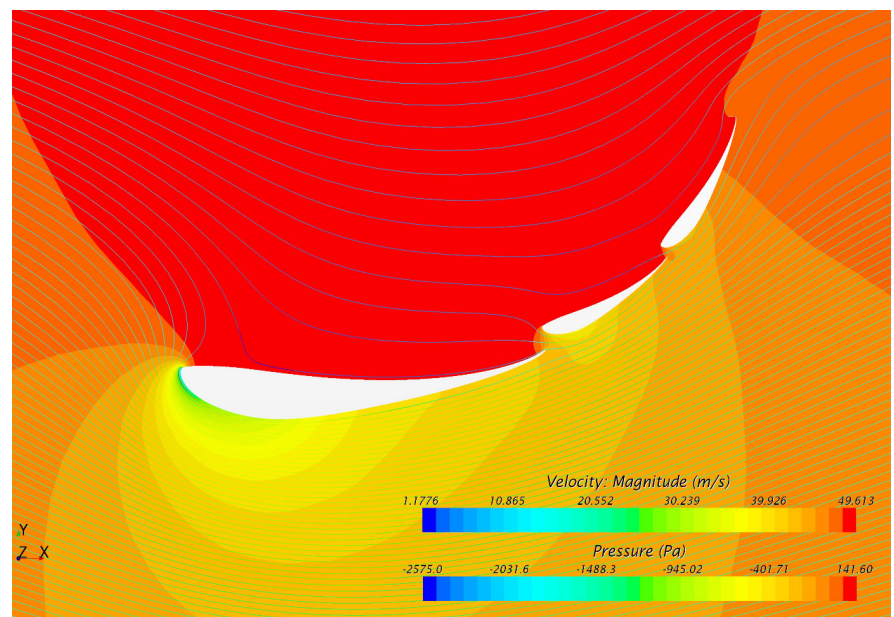

FIGURE 2: 2D CFD simulation - pressure distribution around the airfoil OBRÁZEK 2: 2D CFD simulace - rozložení tlaku okolo kř́́dla

overlap we have used 2D CFD simulations. The advantage of $2 \mathrm{D}$ simulation is its speed. You get the results with quick response so you are able to check a large number of wing configurations. In our case we did over 200 simulations. In the 2D simulations of the airfoils we considered ideal conditions. These can only be achieved with infinite endplates and 3D vortex not appearing here. When we verified the wing setup in 3D simulation the drag rapidly increased to about $700 \%$ and the lift decreased about $11.4 \%$. It was caused by the vortex arising in the tangential direction due to the air flow. This vortex is generated by the inducted drag of the wing near the endplates. The air from the area with the higher pressure (above the wing) is trying to get to the area with lower pressure which is from the outside of the endplates. This effect forms inducted drag of the wing $[5,6]$.

From 2D simulations we have obtained the wing's polar for different flap setups. The polar was specified for the angles

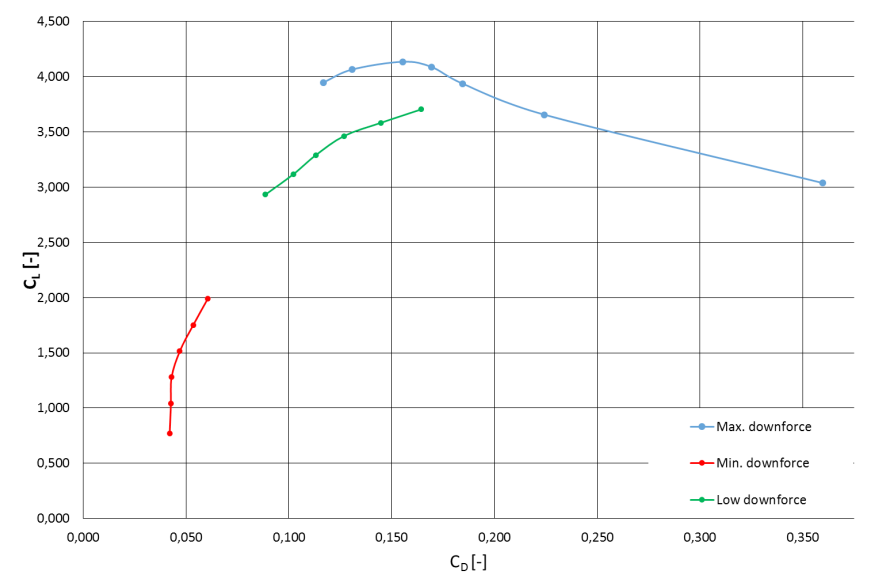

FIGURE 3: Polar's of the wing for different flap's setup

FIGURE 3: Polára pro různá nastavení křídel

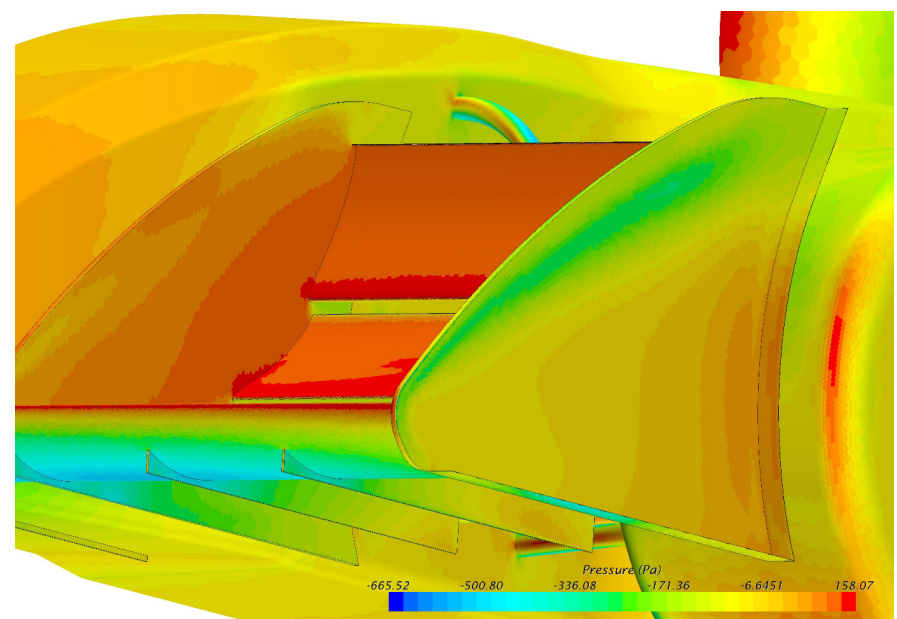

FIGURE 4: Front wing pressure distribution OBRÁzEK 4: Přední kř́́dlo rozložení tlaku

of attack from $0^{\circ}$ to $10^{\circ}$. The angle of attack is changing only in ratio $4^{\circ}$ at the course due to the character of the drive. The other flap setups were created because the characters of the tracks are different in each competition and each discipline requires different setup of whole car. The minimum downforce setup is used at the acceleration. It eliminates the drag penalty. The low downforce is designed for faster tracks with long straight parts, where the drag which is produced by the wings could be significant and the downforce is not so important. We are also able to set different setup at the front and rear wing. So we can change the position of the pressure center depending on our requirements. It is important to get the maximum utilization from wings.

The front wing setup could not be found through 2D simulations. Its behavior is influenced by front wheel that is rotating nearby as mentioned above. The front wing setup had to be found by 3D simulations. We would like to use the ground effect as it was possible because the monocoque structure occupies a third of the size of the wing span. The ground effect depends on ratio between the wing chord line size and the height above the road surface. Our front wing should stand $45 \mathrm{~mm}$ above the road, but this was impossible to achieve due to pitch and roll of the car.

The interesting things on the front wing are the ribs at the wing bottom. These elements are creating chambers that are delaying flow separation and also reducing the vortex between the rotating wheel and the wing. This helps us to reduce the drag about 3\% and to increase the downforce about $7 \%$. Due to the ground effect we could also afford higher angle of attack for all elements [10]. 


\section{PARAMETERS OF THE FRONT WING:}

- chord-line lenght of the main profile: $400 \mathrm{~mm}$

- chord-line of the flaps: $155 \mathrm{~mm}$

- angle of attack of main profile: $6^{\circ}$

- angle of attack of flaps: $30^{\circ}, 30^{\circ}$

- slot gap: $3.6 \%$ chord-line of previous element

- slot overlap: $0.75 \%$ chord-line of previous element

- coefficient of lift: 2.5

- coefficient of drag: 0.61

- mass: $3.2 \mathrm{~kg}$

- aspect ratio: 0.48

- area: $0.73 \mathrm{~m}^{2}$

The rear wing position is a compromise between the downforce and the influence of the center of gravity of the car. It is also important to get the rear wing center of pressure above the rear axle. The final force acting here and its position behind the rear axle causes reduce the load on the front axle. This fact is undesirable because that is working against the front wing. Of course on circuit racing cars the rear wing has the position which is significantly behind the rear axle. It gets the car's center of pressure behind the center of gravity at the longitudinal direction and stabilizes the car at high speeds. For us it has no reason due to the low maximum speed at a race.

\section{PARAMETERS OF THE REAR WING:}

- chord-line lenght of the main profile: $400 \mathrm{~mm}$

- chord-line of the flaps: $155 \mathrm{~mm}$

- angle of attack of main profile: $4^{\circ}$

- angle of attack of flaps: $25^{\circ}, 30^{\circ}$

- slot gap: $3.6 \%$ chord-line of previous element

- slot overlap: $0.75 \%$ chord-line of previous element

- coefficient of lift: 2.81

- coefficient of drag: 0.81

- mass: $3.9 \mathrm{~kg}$

- aspect ratio: 0.48

- area: $0.89 \mathrm{~m}^{2}$

We decided to use the Gurney flaps at the rear edges of the endplates. The Gurney flap is creating the vortex that separates the zones with different pressure. We considered using bigger endplates, but it gives extra weight and we could not pass the rules with them. The height of the Gurney flap is $20 \mathrm{~mm}$. The increment of downforce is $8 \%$ and the drag increment is $2 \%$. $[5,6,7]$.

Of course the car position at the race track is not parallel with the road in the most cases. The car is accelerating, braking and cornering. How these elements influence the downforce and drag is shown in Table 1.

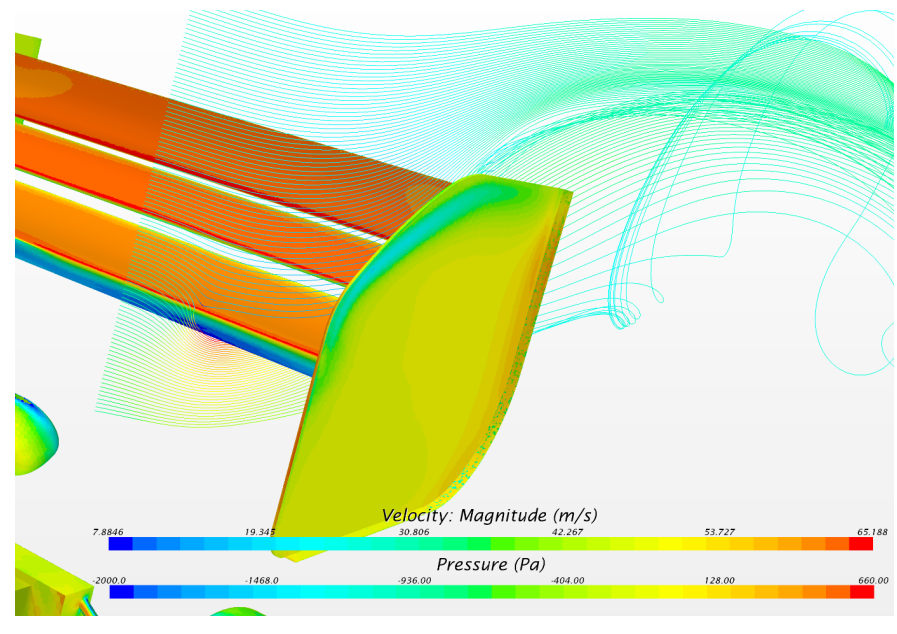

FIGURE 5: Rear wing pressure distribution with streamlines OBRÁZEK 5: Zadní kř́́dlo rozložení tlaku s proudnicemi

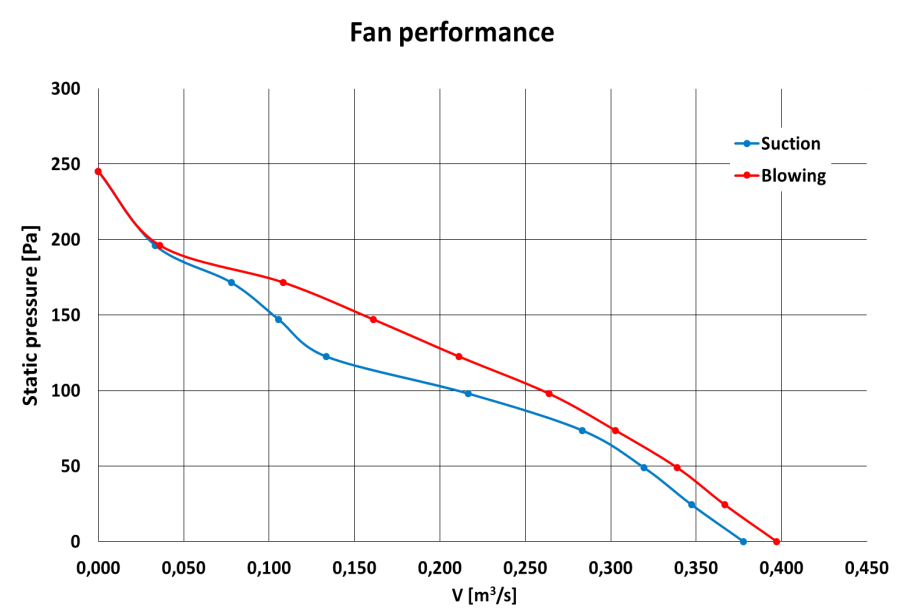

FIGURE 6: Fan performance curve OBRÁZEK 6: Tlakový spád ventilátoru

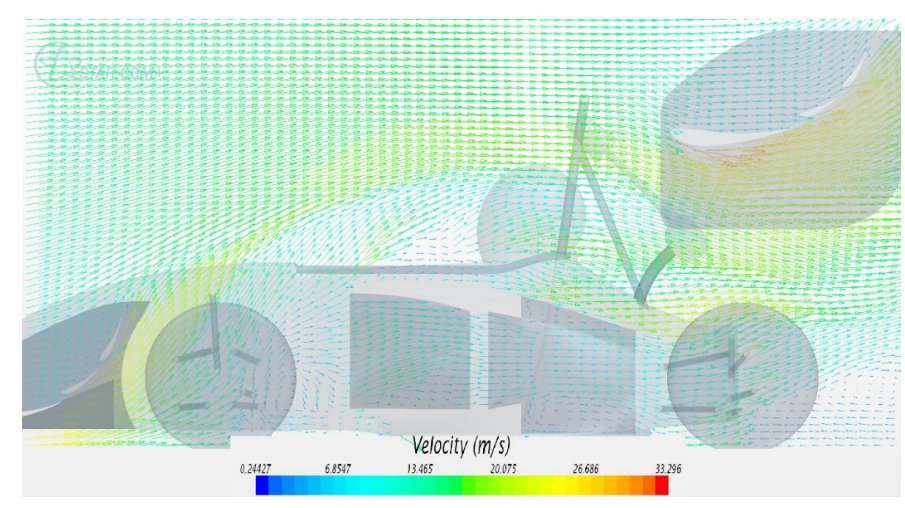

FIGURE 7: Section view of velocity distribution around the car and cooling system

OBRÁzEK 7: Rozložení rychlostního profile okolo vozu a skrz chladící systém 
The front wing is influenced more significantly than the rear wing, because the maximum downforce at the front wing creates the ground effect that is prone on the changes.

The external aerodynamics is not only about the devices that are creating a downforce. To keep the engine working with the best efficiency you have to keep its temperature on the operating values. For the open-wheels car there is the problem with the position of the cooler. You cannot place it to the front part of the car where it is the most effective. Only one option of the position is acceptable in our case, beside the monocoque at the side pod. Its function is influenced by the rotating front tire and also by the front wing. We let the gap between the monocoque and the inner endplate fill the duct with sufficient air volume. The duct that takes the air to cooler has variable cross-section. The narrow area is in the front and the cross-section after that becomes bigger. This shape of the duct transforms the kinetic energy of the air to the pressure one. It helps the air to flow better through the cooler which is made from honey comb structure (has big porosity). Behind the cooler is a fan that keeps the constant air flow through the all spectrum of velocity $[5,8,9]$.

In CFD analysis the cooler was created as a new region of porous type. The data about its properties were taken from manufacturer. The fan was added to the simulation as internal face. The fan interface is a simple model that represents the fan by a zero-thickness interface. The fan performance is described by fan curve. This curve is dependent on the pressure drop between one of variable characteristic value: local velocity, mass average velocity, volumetric flow rate or mass flow rate. We have decided to use the dependence on the volumetric flow rate because we have obtained the data for the curve from the manufacturer. The data to specify the curve were imported in a table from MS Excel. The disadvantage of the fan model is the fact that the interface does not include a swirl. But for our case swirl is not so important because it does not influence other components. The drag coefficient of whole car would be influenced by this effect [3].

There are many options how to find out how the aerodynamic devices work on the car. The most sophisticated way is the wind tunnel measuring. This option gives you exact results how the aerodynamic devices work. The measurement is not influenced by negative effects which are introduced to measures while road testing. On the other hand it is hard to find the wind tunnel where whole car could be tested. The preparing of the measurement is also demanding (moving road, rotating wheels, installing the measure devices etc.). The built area in the tunnel would not be greater than $7 \%$ of the section where the object would be installed. If this condition is not respected, the wall influences the measure

TABLE 1: Downforce and drag influence by driving performance TABULKA 1: Ovlivnění prítlaku a odporu jízdním projevem vozu

\begin{tabular}{|c|c|c|c|c|c|c|}
\hline & \multicolumn{3}{|c|}{ Lift [\%] } & \multicolumn{3}{|c|}{ Drag [\%] } \\
\hline & Front wing & Rear wing & Car & Front wing & Rear wing & Car \\
\hline Stable position & 100 & 100 & 100 & 100 & 100 & 100 \\
\hline Max. front pitch $2,2^{\circ}$ & $-37,8$ & $+6,5$ & $-7,5$ & $+3,0$ & $+2,0$ & $+2,1$ \\
\hline Max. rear pitch $2,2^{\circ}$ & $-20,5$ & $-1,2$ & $-20,7$ & $-6,1$ & $-10,0$ & $+7,7$ \\
\hline Max. roll $1,5^{\circ}$ & $-1,6$ & $-1,5$ & $-3,6$ & 0,0 & 0,0 & $+7,3$ \\
\hline
\end{tabular}

TABLE 2: Comparison of measured and simulated values

TABULKA 2: Porovnání naměřených a simulovaných hodnot

\begin{tabular}{|c|c|c|c|c|c|c|c|c|}
\hline & \multicolumn{2}{|c|}{$\begin{array}{l}\text { Measured downforce } \\
{[\mathrm{N}]}\end{array}$} & \multicolumn{2}{|c|}{$\begin{array}{l}\text { Simulated downforce } \\
{[\mathrm{N}]}\end{array}$} & \multicolumn{2}{|c|}{ Comparison of the downforces [\%] } & \multirow{2}{*}{$\begin{array}{l}\text { Coefficient } \mathrm{cx} \text { form } \\
\text { coast down test }\end{array}$} & \multirow{2}{*}{$\begin{array}{c}\text { Coefficient of drag } \\
\text { cx from CFD }\end{array}$} \\
\hline & $15 \mathrm{~m} / \mathrm{s}$ & $30 \mathrm{~m} / \mathrm{s}$ & $15 \mathrm{~m} / \mathrm{s}$ & $30 \mathrm{~m} / \mathrm{s}$ & $15 \mathrm{~m} / \mathrm{s}$ & $30 \mathrm{~m} / \mathrm{s}$ & & \\
\hline Min. downforce & 255 & 956 & 181 & 1086 & 140,9 & 88,0 & 0,68 & 0,53 \\
\hline Low downforce & 507 & 1797 & 474 & 1654 & 107,0 & 108,6 & 1,02 & 0,99 \\
\hline Max. downforce & 572 & 2094 & 596 & 2575 & 96,0 & 81,3 & 1,25 & 1,20 \\
\hline
\end{tabular}


Acceleration with different wing setup

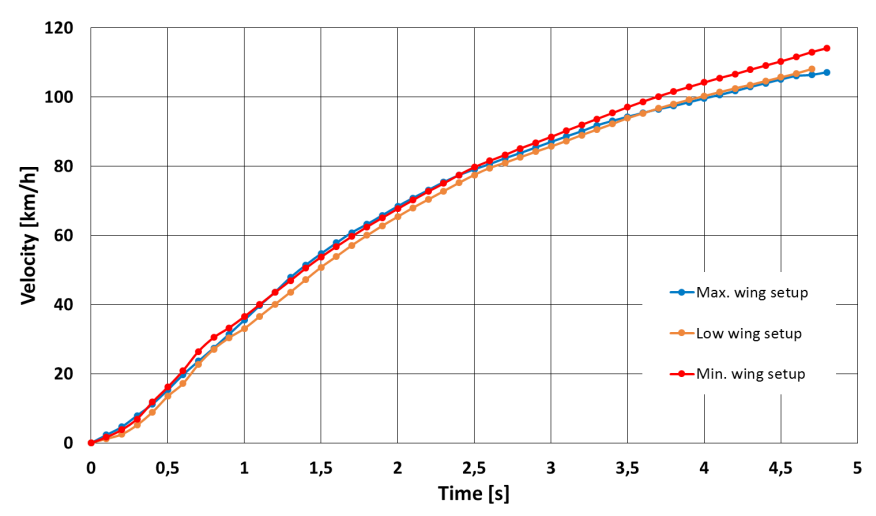

FIGURE 8: Acceleration, vehicle speed versus time

OBRÁzEK 8: Akcelerace, rychlost vozu v závislotui na čas

and you have to use corrections. It is possible to use the scaled model of the car. But it is necessary to keep the correct Reynolds number and with the scaled model you also cannot reproduce so many details which are on the car (radiators, cooling system) $[4,5]$.

The other option is road testing which we have used in our case. The advantage of this measurement is the price and compared to the wind tunnel its simplicity. But the results are not so accurate as the above mentioned works. The other problem is the differences of results due to the driver behavior. In professional motorsport they are so skilled that they can pass the lap in the same track with time difference in thousandth of a second. Similarly it is possible to find differences in various car setups. In our case the short disciplines like slalom, skid pad could be influenced by the driver skills. So it is difficult to separate the difference gained by the changes in a car setup from the differences of the driver behavior by any certainty.

To measure the downforce of the wings the car went straight with steady speed. We measured the bump of the dampers. Because the response on the throttle is so sensitive we set the velocity limiter in the ECU. We measured two drives there and back with and without the wings and compared the bump. After we have recalculated the bump of the dampers by their

TABLE 3: Car deceleration

TABULKA 3: Zpomalení vozu

\begin{tabular}{|lc|}
\hline Wing setup & Car deceleration $[\mathrm{G}]$ \\
\hline Minimal downforce & 1.42 \\
\hline Maximum downforce & 1.63 \\
\hline
\end{tabular}

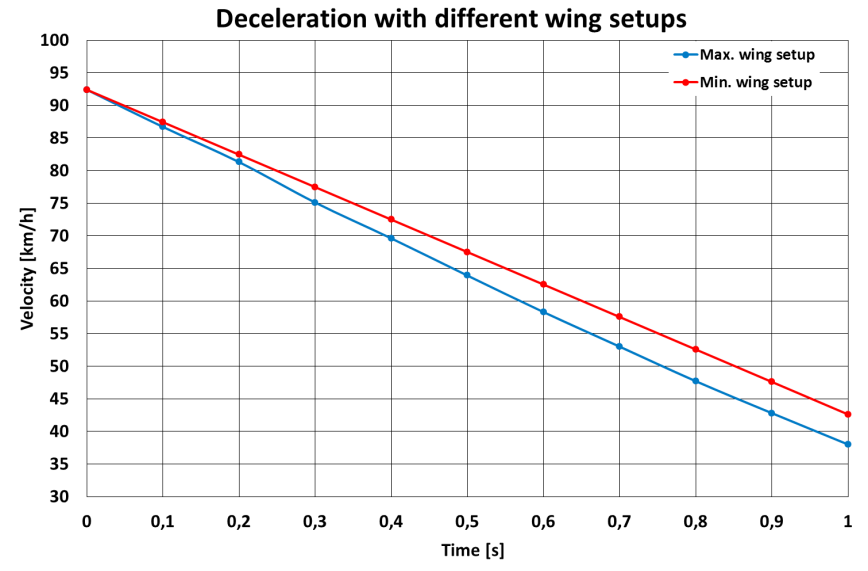

FIGURE 9: Deceleration, velocity versus time OBRÁzEK 9: Brzdění, rychlost vozu v závislosti na čase

steering to get the force on the wheel in normal direction to the road. Results are shown in Table 2.

The coefficient of the drag was specified by coast down test. The coefficient of drag was determined from the deceleration of the car in high speed range because the drag increases quadratic with velocity. So in range of higher speeds it has the biggest part on decelerating and we can neglect effect of rolling resistance and also the friction of rotating components.

We are satisfied with the measured values of the downforce, because we assumed there would be a bigger difference. However only validating the wing parameters and the drag coefficient of the car does not give us the answer how the aerodynamic devices are beneficial in Formula Student. It was necessary to obtain this information in the disciplines. We have tested how the different wing setups affected the driving parameters of the car in different track performance like acceleration, deceleration, slalom and autocross/endurance track $[5,11]$.

In the acceleration the car with minimal downforce wing setup (minimal drag wing setup) achieved the speed 100 $\mathrm{km} \cdot \mathrm{h}^{-1}$ faster than the version with maximum downforce and also obtained higher speed at the track of the same distance as shown in Figure 8. Interesting thing is that the difference between the wing setup is negligible up to $75 \mathrm{~km} \cdot \mathrm{h}^{-1}$. Over

TABLE 4: Lap time performance

TABULKA 4: Porovnání dosažených výkonů

Wing setup

Best lap time [s]

Median of speed $[\mathrm{km} / \mathrm{h}]$

Maximal downforce

28.77

50

Minimal downforce

31.18

46.5 
this speed drag penalty becomes more significant to benefit for the minimal drag wing setup. However, this may also be caused by the driver's mistake.

The comparison of braking performance is shown in Figure 8. The curve of maximum downforce setup has greater gradient. This is caused by considerable longitudinal acceleration due to bigger drag in range of higher speed and also more normal force is generated on the wheels so the brake force could be higher. The decelerations which have been achieved are shown in Table 3.

The track for autocross/endurance testing was 400 meters long, consists of curves with radius $5,7,8,9,10 \mathrm{~m}$, one straight with $50 \mathrm{~m}$ length and one series of $8 \mathrm{~m}$ slalom. The surface was concrete. The track profile is shown in Figure 10. The driver has gone 10 laps for each different wing setup and we have compared the most frequent lap times for each setup. The lap time difference for maximum downforce setup and without the wings was 2.4 seconds. Although this could be caused by the driver influence, the time difference is too big for the lap time with the most occurrence. More reliable results could have been obtained if the driver could pass more laps (for example about 30) or if we could compare the times for the endurance distance and not for one lap. This was impossible due to time limitations and having only one tire set for the testing. If we recalculate the time difference for the length of the endurance, the time difference will be above 2 minutes. The time difference of 2 minutes is the same as the time penalty for 60 dropped cones. The comparison of the car speed on distance is shown in Figure 11. At the bottom of the figure is shown the time difference which is significantly increasing at the curve part of the track.

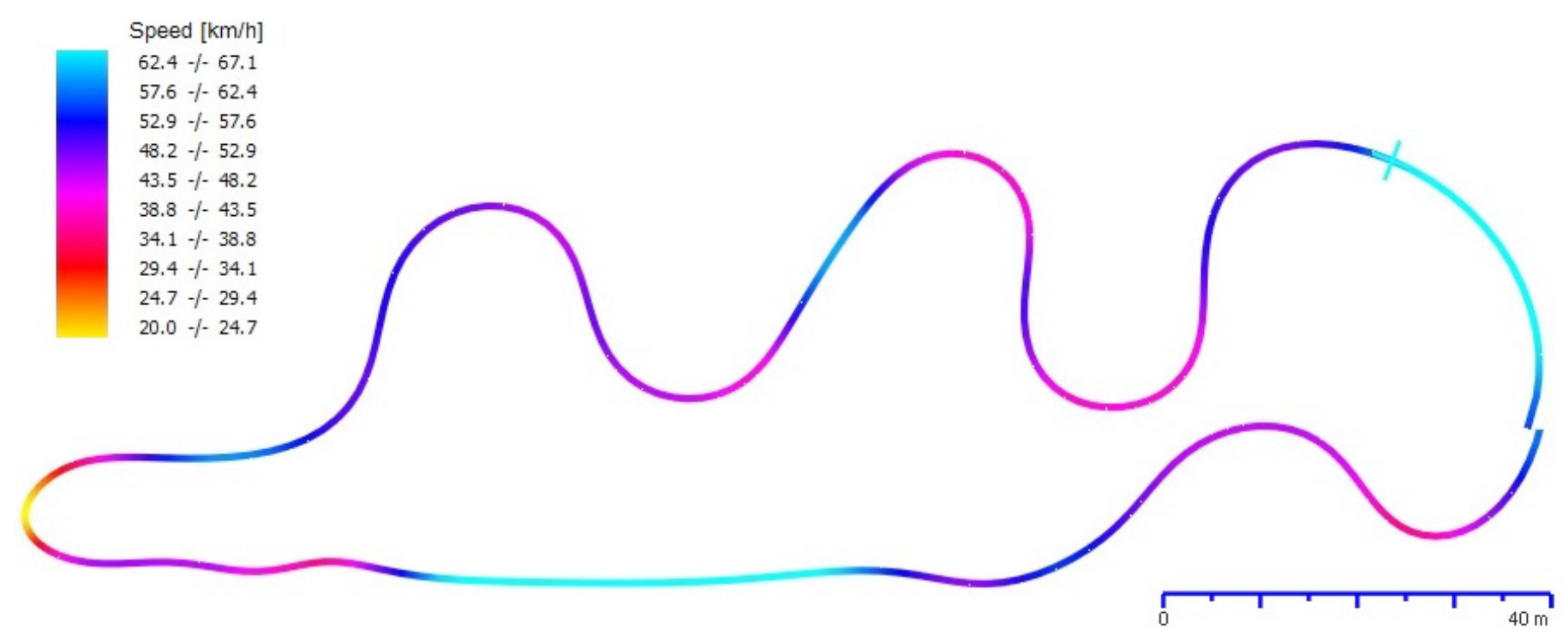

FIGURE 10: Track profile OBRÁZEK 10: Profil tratě

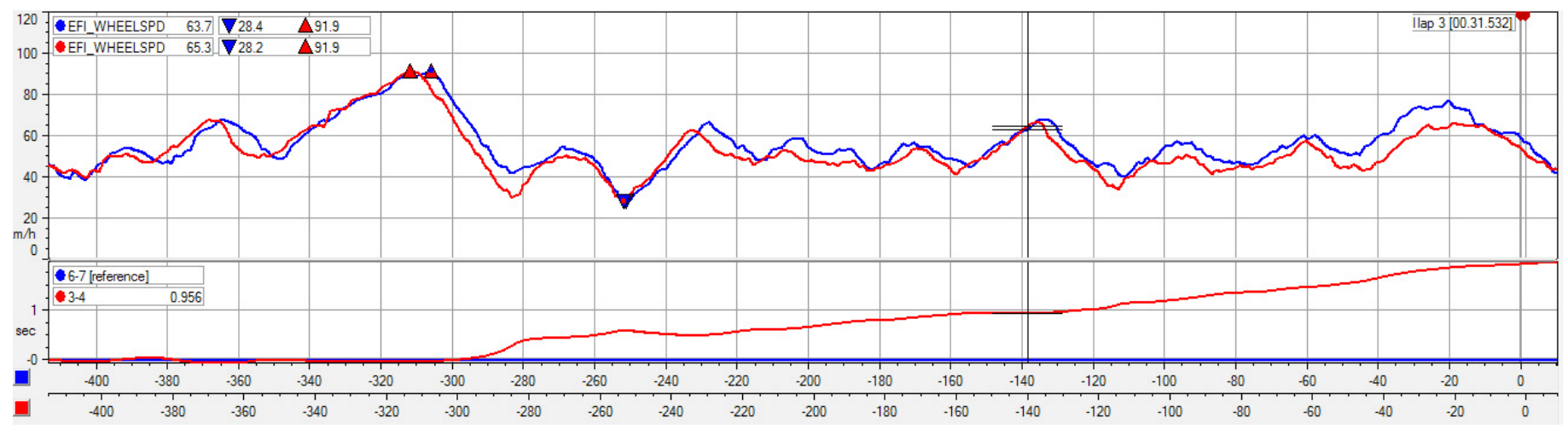

FIGURE 11: Velocity comparison on distance for different wing setups OBRÁZEK 11: Porovnání rychlosti v závislosti na ujeté vzdálenosti 


\section{CONCLUSION}

Thanks to CFD analysis we have gotten the maximum performance from the aerodynamic devices. Also we have made design methodology how to proceed with CFD analysis. The values of measured downforces have proved us that we are able to design and make the aerodynamics elements. From the comparison of the winged car and without wings is evident that the car with wings is not slower as someone could suppose for the Formula Student dynamic events. To determine the clear benefit of the wings we have to do more tests and measurements. For next year we would like to add diffuser that can reduce the drag of the car with downforce increase and make more complex model of fan also with heat transition at cooler.

\section{ACKNOWLED GEMENT}

This work was supported by the Grant Agency of the Czech Technical University in Prague, grant No. SGS13/183/ OHK2/3T/12

This research has been realized using the support of EU Regional Development Fund in OP R\&D for Innovations (OP VaVpl) and The Ministry of Education, Youth and Sports, Czech Republic, project \# CZ.1.05/2.1.00/03.0125. Acquisition of Technology for Vehicle Center of Sustainable Mobility. This support is gratefully acknowledged.

This research has been realized using the support of The Ministry of Education, Youth and Sports program NPU I (LO), project \# L01311 Development of Vehicle Centre of Sustainable Mobility. This support is gratefully acknowledged.

\section{REFERENCES}

[1] 2014 Formula SAE Rules, [online, 06-10-2014], http://students.sae.org/cds/formulaseries/rules/2014_ fsae_rules.pdf

[2] Desai, S., Leylek, E., Betty Lo, C., Doddegowda, P., Bychkovsky, A., and George, A.R., Experimental and CFD Comparative Case Studies of Aerodynamics of Race Car Wings, Underbodies with Wheels, and Motorcycle Flows, SAE Paper 2008-01-2997, 2008.

[3] Author CD-Adapco. User Guide - Star CCM+ Version 9.02

[4] S. Wordley, J. Saunders. Aerodynamics for Formula SAE: A Numerical, Wind Tunnel and On-Track Study, SAE Paper 2006-01-0808, 2006

[5] J. Katz. Race Car Aerodynamics, Bentley Publishers, Massachusetts, ISBN 978-0-8376-0142-7, 2006.

[6] W. F. Milliken and D. L. Milliken. Race Car Vehicle Dynamics, SAE International, ISBN 1-56098-526-9, 1995

[7] J. Roy, D. Landman, Aerodynamic Characterization of a Sportscar Prototype Racecar Using Design of Experiments in a Wind Tunnel Test, SAE Paper 2006-01-3621, 2006

[8] H. Siitonen. Improving the aerodynamics of a cooling system of a Formula Student car, 13-12-2011, [online, 8-10-2014], https://www.theseus.fi/bitstream/ handle/10024/37408/0ppari_Aerodynamics. pdf? sequence $=1$

[9] A. Šumelda. Karosérie vozu Formula Student, DP 2013 - MV 17, 2013

[10]X. Zhang, W. Toet and J. Zerihan. Ground Effect Aerodynamics of Race Cars, Applied Mechanics Reviews, 2006.

[11]S. Wordley, J. Saunders and J. Pettigrew Aerodynamics for Formula SAE: On-Track Performance Evaluation, SAE Paper 2007-01-0897 